desperately poor all his life, devoted his slender resources, great energy and genius to the production of his American Ornithology. Audubon, his successor, is naturally included (for Adams is the author of a definitive study, John James Audubon (1967)). Humboldt, Lyell, Darwin, Wallace, Huxley and Mendel bring the history up to the beginning of the present century.

The personalities of these naturalists were so difforent that this study makes a fascinating human document. Some wero modest, some arrogant, but all were driven by an invisible demon of discontent with accepted ideas, and were therefore continually searching for a tenable position. Whatever one's personal quibbles over the omission of some favourite naturalist, Adams's Eternal Quest is a "wide screen" treatmont of the development of natural history, giving a balanced and broad picture of absorbing interest to the general reader and an introduction to the subject.

ALWYNE WHEELER

\section{SCIENCE FOR SCHOOLS}

\section{Nuffield Combined Science Pack I}

Activities-Book 1: Pp. 72; Book 2: Pp. 66; Book 3: Pp. 40; Book 4: Pp. 47; Book 5: Pp. 36. Reference Sheets: Pp. 27. Teachers' Guide 1 (Sections 1-5): Pp. xxiii +411 . 'Teachers' Guide 3: Pp. vii +266 . (Longman: London; Penguin: Harmondsworth, Middlesex, 1970.) n.p.

TH1s is the first batch of materials for use with the now Nuffield Combined Science course for 11 to 13-yoar-olds. Teachers' Guide 2 and five rnore Activities booklets will complete the set.

Any attempt at really integrating the various branches of scientific knowledge so that the product is satisfying for both teacher and taught faces major problems. These problems are concentrated in the selection of inaterial and its presentation in such a way that the users do not get the feeling of hopping haphazardly from ons topic to another. In general, the four authors of this course can feel reasonably satisfied with their efforts at coherence and clear presentation. It is instructive to compare the Nuffield course with two other attempts at integration: the Science Worksheets prepared by the Scottish Secondary Science Working Party (published by Heinemann Educa. tional Books), and Professor Harry Messel's Science for High School Students (University of Sydney). There are many similarities in the outlook and approach of the three groups and also in their choice of experimental and illustrative material.

The important thing about any new course is how the consumers react to it. The trials for this one involved thirtr-five schools, eighty teachers, and three thousand children; and, making an allowance for the inevitable Hawthorno effect, there is good evidence that the materials were well received. Teachers' Guide 1 quotes many comments (not all of them complimentary) from the teachers involved. The authors claim that the course can be adapted for use with the whole range of ability, and there is a useful appendix consisting of eomments from teachers who used it with slow learners.

The authors of the Teachers' Guides successfully walk the tightrope botween appearing to be dogmatic and definitive (so cramping the origmality of the teacher), and failing to give adequate guidance to those many teachers who will have to deal with topics outside the range of their personal knowledge. T'eachers' Guide 3 is a reference book: full of useful hints, details of apparatus, materials, and teaching aids, with a mathematics appendix. Teachers' Guide 1 ties in with the Activities booklets for the pupils. Both Guide and booklets are well illustrated, and the instructions are detailed without being fussy. The booklets are clear and readable, but will probably have to be troated as expendable. The Guide contains some excellent educational philosophy; the introduction to the section on "Looking for Patterns" is particularly impressive. There is a welcome emphasis on doing simple experiments at home; and in places one can detect the influence of that seminal classic, UNESCO's Source Book for Science T'eaching.

There are three major limitations to curriculum innova. tion in science: the capacity of the teachers, the time allocated within the school curriculum, and monor. This particular course is intended to be taught by ore teacher throughout. I, for one, could not do it withont, an extensive period of in-service training; for example, how many physics and chemistry teachers would back themsolves to dissect a rat properly, even with full printed and photographic instructions? Also, there is currently an absolute shortage of science teachers, particularly for the physical sciences (vide the Royal Society's recent report). The Nuffield group suggests that this courso should occupy five periods per woek. I would regard this as an absolute minimum; but many head. masters and more particularly headmistresses would think it too much, espocially for the first year. The authors also warn that the costs of the Nuffield Combired Science are likely to be higher than for some other schemes.

All those concerned with the teaching of science in the carly secondary years should give serious considerations to these books.

MaRTYN BERRY

\section{ISLAND RIDDLES}

\section{Serendipity in St Helena}

A Genetical and Medical Study of an Isolated Community. By Ian Shine, with the assistance of Reynold Gold. Pp. $x v+187$. (Porgamon: Oxford and New York, 1970.) n.p.

Eridemiolouists are said te plan their studies by first defining their population, and there are few studies whose success has turned upon the chance discovery of a population. Such, however, was the good fortune of the author of this monograph who found himself, by chance, medical officer to a remarkable island population. The ancestors of St Helena's population today were Europeans, Indians, Africans and Chinese who arrived voluntarily or by force and who have interbred over the past three hundred years to a remarkable extent. The 4,642 men, womon and children who live there today consequently form a uniquely interbred and even inbred mixture of races in, whom the pattern of discase might be expected to be unusual. The author's survey by exarnination and questioning of ninet $y$ per cent of the population did, in fact, bring to light an unusually high incidence of some rare congenital disorders, though it also showed the islanders to be remarkably healthy. Not all the author's findings are analysed in this monograph, which deals largely with the incidence of congenital defects of a structural or metabolic type and with a study of eighty-seven consanguincously derived propositi and of a similar number of non-inbred controls.

Having found that the incidence of albinism, deaf mutism, mongolism, Christmas disease, microphthalmitu and some other rare defects was remarkably high compared with that in other studies, the author remained unable to explain his results. Inbreeding provided him with part explanation, but it was not enough to account for the high frequency of recessive traits. Migration from the island, genetic drift, selection and mutation were all considered and found inadequate on the basis of current knowledge. The resulting conundrum posed by the author will be a challenge to others interested in population genetics.

Taken all-in-all, the St Helenians seem to bo a happy race, though they suffer from asthma to an unusual extent, from ischaemic heart disease in spite of walking habitually, and from hallux valgus. Only in the case of the latter can the disease be clearly attributed to the environmentnamely to wearing shoes. Charues Strart.Harris 